\title{
THE EFFICACY OF DHATRILOHAM IN PANDU W.S.R TO IRON DEFICIENCY ANAEMIA IN SCHOOL GOING CHILDREN
}

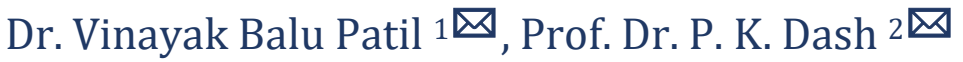 \\ ${ }^{1}$ P.G (Scholar) Department of kaumarbhritya, Yashwant Ayurvedic College Post Graduate Training \\ \& Research Center, Kodoli, Tal - Panhala, Dist - Kolhapur, India \\ 2 M.D., Ph.D. (Ayurved) (Kaumarbhritya), Department of kaumarbhritya, Yashwant Ayurvedic \\ College Post Graduate Training \& Research Center, Kodoli, Tal - Panhala, Dist - Kolhapur, India
}

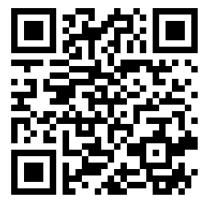

DOI: https://doi.org/10.29121/granthaalayah.v8.i7.2020.813

Article Type: Review Study

Article Citation: Dr. Vinayak Balu Patil, and Prof. Dr. P. K. Dash. (2020). R THE EFFICACY OF DHATRILOHAM IN PANDU W.S.R TO IRON DEFICIENCY ANAEMIA IN SCHOOL GOING CHILDREN. International Journal of Research GRANTHAALAYAH, 8(7), 354-357. https://doi.org/10.29121/granthaa layah.v8.i7.2020.813

Received Date: 18 July 2020

Accepted Date: 31 July 2020

Keywords:

Dhatriloham Pandu Vhyadhi

Iron Deficiency Anaemia

School Going Children

\section{ABSTRACT}

Ayurveda is one of the most ancient systems of life, health and cure. This system of knowledge flourished thoroughly over 3000 years. The frame of Ayurveda is that its treatment still holds the field in spite of so many advances in modern science.

Pandu roga is pitta-pradhan vhyadhi. In Pandu roga tissue metabolism get affected due to Vitiated doshas which turn into dhatu-shyathilya in all dhatu. Iron deficiency anaemia is frequently founded under nutritional anaemia. Iron deficiency anaemia is not limited upto haematological condition but involves in multiple system. Its show similarity of pandu vhyadhi with Iron deficiency anaemia. It's mostly seen in school going children. Stressful lifestyle and defective and un-nutritional diet lead to Iron deficiency anaemia.

Dhatriloham is medicine described in Ayurvedic literature. It is Krimighna, Balya and Raktavardhaka in Pandu vhyadhi. This description comes in Bhaishajyaratnavali.

Therefore, the in present paper trying to focus on relationship of Dhatriloham on pandu vhyadhi W.S.R. to iron deficiency anaemia in school going children.

\section{INTRODUCTION}

Ayurveda literally means knowledge of life. Kaumarbhritya is a section of Ayurveda dealing with child life with special emphasis on nutrition of children. According to Kashyapa, Paediatrics is the most important division of medicine as the other divisions play their role only after child matures into an adult.

Ayurveda provides a long and happy life. One among the eight Angas of Ayurveda,"Kaumarbhritya" specially deals with the problems related with infants and children. It is peculiarity of Ayurveda that, "Kaumarbhritya." starts right from conception [1] It deals with antenatal, perinatal and postnatal care along with the different aspects of child health and disorders.

Pandu vhyadhi is commonest nutritional disorder all over world and form a major problem of mankind especially in a country like India, due to low economic status, illiteracy and malnutrition in a major part of population. It affects the physical and mental health of children, affects school performance and increases susceptibility to various infections.

(C) 2020 The Author(s). This is an open access article distributed under the terms of the Creative Commons Attribution License, which permits unrestricted use, distribution, and reproduction in any medium, provided the original author and source are credited. 
It is Vyadhi of Rasavahasrotas and also associated with Raktavahasrotas. Pandu can be clinically correlated with Iron deficiency anaemia as its sign and symptoms of both are similar.

Iron deficiency anaemia is most common disease of childhood in developing countries. [2] Because of low economic status, illiteracy and Nutritional deficiency the incidence of this disease is increasing day by day. The prevalence of iron deficiency anaemia was 70\% in children aged 6-59 months. The estimated prevalence of Iron deficiency anaemia in developing countries is $39 \%$ in children $<5$ years, $48 \%$ in children $5-14$ years. Iron deficiency anaemia affects the physical and mental health of children. [3]

2. AIM

- $\quad$ To evaluate The Efficacy of Dhatriloham in Pandu W.S.R to Iron Deficiency Anaemia in School Going Children.

\section{OBJECTIVES}

- $\quad$ To study the Pandu vyadhi in detail.

- To study the Dhatri Loham in details.

- To study the effect of Dharti Loham on sign and symptoms in pandu w.s.r to IDA in school going children

- To study the iron deficiency anaemia in detail.

\section{MATERIAL AND METHODS}

\subsection{MATERIAL}

For the present review study deeply literary study is performed.

The Data and references are analysed from available samhita. For detail study references are taken from previous thesis and Research articles available from internet.

\subsection{METHODOLOGY}

In this paper it is tried to correlate relationship of Dhatriloham on pandu vhyadhi W.S.R. to iron deficiency anaemia in school going children.

\section{DISCUSSION}

\subsection{DISCUSSION ON DISEASE}

\subsubsection{PANDU VHYADHI}

In Ayurveda, detail description about Pandu vhyadhi is found in Bruhtrayees s well as Laghutrayees. References of Pandu vhyadhi found in Kashyap Samhita also. As per Ayurveda Pandu vhyadhi is Rasapradoshaja and Pittapradoshaja, Tridoshajvyadhi. [4] Dourbalya, Bhrama, Gatrashool Swasa, Shishirdvesha, Gaurva are lakshan of Pandu vhyadhi. [5]

Rakta has been considered as akey factor for jeevana, Prinana, Dharana and Poshana karma of body. Many a times it is seen that Rakta get vitiated by Doshas mainly by pitta doshaas Rakta is pittavargiya and disease like pandu occur.

\subsubsection{IRON DEFICIENCY ANAEMIA}

Iron deficiency anaemia is most widespread and common nutritional disorder in the world. It is estimated that $30 \%$ of the global population has iron deficiency anaemia, most of them live in developing countries. [6] 
The most important clinical sign of iron deficiency anaemia is pallor but it is not visible until Haemoglobin fall below 7-8 gm/dL. It is most readily noted as pallor of the palms palmer creases nail beds or conjunctivitis. When the Haemoglobin level falls below $5 \mathrm{gm} / \mathrm{dL}$, irritability anorexia and lethargy develop, and systolic flow murmur are often heard. As the Haemoglobin continue to fall, tachycardia and high output cardiac failure can occur. Hence it is important to treat IDA in early stage to avoid further complications.

\subsubsection{SCHOOL GOING CHILDREN}

Mostly of children busy in playing game and gazettes all. Inadequate intake of nutritional food stuff, irregular deictic habit, mal absorption, consumption of fast foods are major cause of pandu vhyadhi (iron deficiency anaemia) all his habit of children make them ill. Another cause of iron deficiency anaemia in school going children is parasitic infection. [7] Nutritional status of children not only depend upon availability of nutritional food but food habit and metabolism also. irregular food habit, over eating, inadequate diet, consumption of fast and junk foods are interfere with metabolism and create nutritional deficiency.

\section{DISCUSSION ON DRUG - DHATRILOHAM [8]}

Table 1: Showing Discussion on Dhatriloham

\begin{tabular}{|c|c|c|c|c|c|}
\hline Dravya & Latin name & Rasa & Virya & Vipaka & Karma \\
\hline Guduchi & Tinospora Cordifolia & Tikt, Kashay & Ushna & Madhura & Tridosh Shamak. \\
\hline Yastimadhu & Glycyrrhizaglabra & Madhura, & Sheet & Madhura & Vatt, pitta shamak \\
\hline Lohbhasm & Calcined Iron & Madhura & Sheet & Madhura & Kapha-pitta shamak \\
\hline Amalaki & Embelica officinale & Panchrasa & Sheeta & Madhura & Tridosh Shamak \\
\hline
\end{tabular}

\subsection{ACTION OF DRUG (DHATRILOHAM) ON PANDU VHYADHI}

- Amalaki is main ingredient of dhatri Loha, which is pittapradhana tridoshshamka. Predominate Dosha of pandu same, so action of drug directly act on main Dosha of pandu. [9]

- Rasayana karma of Amalaki is very well known. Pandu is rasa pradoshaja vhydhi so Amalaki work perfectly here also.

- Few study said that, iron deficiency anaemia can cause absorptive defect by damaging epithelium layer of small intestine. Deepan and pachana karma of Guduchi and Amalaki can correct above defect of intestine.

- Amalaki has chelating ability of iron by which bio availability of iron may enhance.

- Amalaki is rich sources of vit-c which enhance absorption level of iron. [10]

- Amalaki, Guduchi, yashtimadhu all are yakrutojaka dravyas.

\section{CONCULSION}

The Ayurvedic Iron compound preparation due to its ingredients may prevents the common hazards of conventional Allopathic oral Iron therapy like gastrointestinal upset, abdominal discomfort, constipation, iron intolerance etc. The purpose of this study is primarily to establish the efficacy of this drug as it is cost effective and having no side effects.

So this study is an attempt to find a better solution for the treatment of Pandu vhyadhi with special reference to Iron deficiency anaemia. This is the simple remedy which will be helpful to cure the condition like Pandu vhyadhi in children with a simple way.

\section{SOURCES OF FUNDING}

This research received no specific grant from any funding agency in the public, commercial, or not-for-profit sectors. 


\section{CONFLICT OF INTEREST}

The author have declared that no competing interests exist.

\section{ACKNOWLEDGMENT}

None.

\section{REFERENCES}

[1] Acharya Ambikadatt shastri, Sushrut Samhita Purvardha, Vedotpattiadhyaya, - Chaukhamba Sanskrit Pratishthan, reprint 2016,1/13, page no. 3

[2] Samir K Bhadri \& Roopa Bhat: Clinical Evaluation of Laghu Panchamoola Kwatha As an Adjuvant Therapy In The Management Of Pandu Roga With Special Reference To Iron Deficiency Anaemia, IAMJ: Volume 3, Issue 6, August-September, 2019. Page no.1948.

[3] https://en.m.wikipedia.org/wiki/iron-deficiency_anemia (20 july 2020: 12.30 pm)

[4] Acharya Vidyadhar Shukl and Prof.Ravidatta Tripathi, Charak Samhita, Pandurogachikitsadyaya, Chaukhamba Sanskrit Pratishthan, Reprint 2015, 16/119-120, page no. 610.

[5] Dr.Kashinath Sastri \& Dr Gorakhnath, Chaturvedi, Charaka Samhita, Vidyotini hindi commentary, Chowkhamba Bharati Academy, Varanasi, 22nd edition 1993, Chikitsa Sthana 16/4-6, Page no. 487.

[6] http://www.who.int/nutrition/topics/ida/en/ (22 july 2020: 3 pm)

[7] Nelson text book of pediatric1st south asia edition, volume-2 Robert. M. Kliegman,Chapter -447, Page no.2323.

[8] Vd.gopinath, Bharat bahishajaya ratnakara, part-3, pandu nidan, adhaya-12, page no.3331.

[9] The ayurvedic pharmacopoeia of india-part-1, gov.of india ministry of health \& family welfare dep.of AYUSH.new delhi; vol-1, pg.no-8.

[10] https://en.m.wikipedia.org/wiki/phyllanthus_emblica (22 july 2020: 3 pm) 